\title{
PENGARUH PELATIHAN DAN PROMOSI JABATAN TERHADAP KINERJA KERJA KARYAWAN PADA PT. PERMODALAN NASIONAL MADANI (PERSERO)
}

\author{
1Siti Husna, ${ }^{2 *}$ Yulian Bayu Ganar \\ Universitas Pamulang, Tangerang, Banten, Indonesia \\ *dosen01534@unpam.ac.id
}

\begin{abstract}
Abstrak
Tujuan pada penelitian ini adalah untuk mengetahui pengaruh pelatihan dan Promosi Jabatan terhadap kinerja karyawan pada PT. Permodalan Nasional Madani (persero).Metode yang digunakan adalah metode kuantitatif. Teknik sampling yang digunakan adalah metode teknik sampling Purposive dengan sampel sebanyak 75 responden. Analisis data menggunakan analisis regresi, analisis koefisien korelasi, analisis koefisien determinasi dan uji hipotesis. Hasil penelitian ini adalah pelatihan berpengaruh positif dan signifikan terhadap kinerja karyawan sebesar $97 \%$. Uji hipotesis simultan pelatihan dan promosi jabatan berpengaruh positif dan signifikan terhadap kinerja karyawan dengan koefisien determinasi sebesar 94,2\%, sedangkan sisanya sebesar 5,8\% dipengaruhi faktor lain. Uji hipotesis diperoleh nilai F hitung > F tabel atau (32.925> 1,995), dengan demikian Ho ditolak dan H3 diterima. Artinya terdapat pengaruh positif dan signifikan secara simultan antara pelatihan dan disiplin kerja terhadap kinerja karyawan pada PT. Permodalan Nasional Madani (persero).
\end{abstract}

Kata Kunci: Pelatihan, Promosi Jabatan, Kinerja Karyawan

Abstract

The purpose of this study was to determine the effect of training and job promotion on employee performance at PT. Permodalan Nasional Madani (Persero). The method used is a quantitative method. The sampling technique used was purposive sampling technique method with a sample of 75 respondents. Data analysis used regression analysis, correlation coefficient analysis, determination coefficient analysis and hypothesis testing. The result of this research is that training has a positive and significant effect on employee performance by $97 \%$. The simultaneous hypothesis test of training and promotion has a positive and significant effect on employee performance with a determination coefficient of $94.2 \%$, while the remaining $5.8 \%$ is influenced by other factors. Hypothesis testing obtained the value of F count> F table or (32,925> 1.995), thus Ho is rejected and H3 is accePT.ed. This means that there is a positive and significant effect simultaneously between training and work discipline on employee performance at PT. Permodalan Nasional Madani (Persero).

Keywords: Training, Job Promotion, Employee Performance.

\section{PENDAHULUAN}

PT. Permodalan Nasional Madani (Persero) didirikan Pemerintah pada 1 Juni 1999. PT. Permodalan Nasional Madani (Persero) melakukan transformasi bisnis dengan meluncurkan produk PNM ULaMM (Unit Layanan Modal Mikro) yang memberikan pembiayaan secara langsung kepada pelaku usaha mikro dan kecil.

Permasalahan yang paling signifikan yang terdapat di dalam suatu pengembangan karir dan pelatihan dalam kinerja karyawan yang kurang mendalami ilmu yang ada di dalam perusahaan.
Pelatihan ini lah yg mampu menentukan kualitas dan kinerja seorang karyawan. Apabila seorang karyawan dengan sedikit ilmu pengetahuan dapat mengurangi kinerjakaryawan.

Pelatihan bagi karyawan merupakan sebuah proses yang mengajarkan pengetahuan dan keahlian tertentu, sehingga karyawan akan semakin terampil dan mampu melaksanakan tugas dan tanggung jawabnya dengan baik. Dengan adanya program pelatihan kerja akan membantu perusahaan untuk mencapai tujuan organisasi. Disamping itu pelatihan 
bagi karyawan juga bermanfaat untuk meningkatkan mutu, keterampilan, kemampuan, dan keahlian karyawan dalam menjalankanpekerjaannya.

Hal ini juga akan berdampak kepada kinerja karyawan yang meningkan melalui pelaksanaan program pelatihan kerja yang diadakan pada suatu perusahaan akan menyebabkan karyawan memiliki kualitas yang baik dan mempunyai keahlian untuk melaksanakan tugas dan kewajibannya.

Pelatihan juga merupakan suatu proses pengajaran kepada pekerja secara sistematis untuk mendapatkan dan memperbaiki keterampilan dan Pengetahuan yang berkaitan denganpekerjaan.

Jika suatu program pelatihan terselenggara dengan baik, sungguh banyak manfaat yang dapat dipetik oleh para karyawan seperti peningkatan, kemampuan mengambil keputusan, penerapan ilmu dan keterampilan yang baru dimiliki, kesediaan bekerja sama dengan orang lain, motivasi

untuk berkembang yang semakin besar, peningkatan kemampuan melakukan penyesuaian perilaku yang tepat, kemajuan dalam meniti karier, peningkatan penghasilan dan peningkatan kepuasaan kerja.

Pelatihan dilakukan untuk menutup "gap" antara kecakapan atau kemampuan karyawan dengan permintaan jabatan serta untuk meningkatkan efisiensi dan efektifitas kerja karyawan.

PT. Permodalan Nasional Madani (persero) menyadari bahwa sumber daya manusia merupakan suatu aset yang sangat penting dan paling berharga karena keberadaannya sangat menentukan terhadap kinerja suatu perusahaan, melihat perannya sumber daya manusia terhadap kemajuan perusahaan, maka PT.. Permodalan Nasional Madani (persero) telah memiliki suatu system pelatihan individu pada semua karyawan lini dalam organisasi perusahaan.

\section{TINJAUAN PUSTAKA}

1. Pengertian Pelatihan
Pelatihan adalah suatu proses yang meliputi serangkaian tindak (upaya) yang dilaksanakan dengan sengaja dalam bentuk pemberian bantuan kepada tenaga kerja yang dilakukan oleh tenaga profesional kepelatihan dalam satuan waktu yang bertujuan untuk meningkatkan kemampuan kerja peserta dalam bidang pekerjaan tertentu guna meningkatkan efektivitas dan produktivitas dalam suatuorganisasi.

2. Pengertian Promosi Jabatan

Di dalam mempertahankan dan meningkatkan produktivitas suatu perusahaan, maka peran manajemen sumber daya manusia sangatlah penting. Dalam hal tersebut perusahaan berkewajiban memperhatikan kebutuhan karyawan baik yang bersifat materiil maupun non materil. Wujud dari perhatian, usaha serta dorongan yang dapat dilakukan oleh perusahaan terhadap karyawannya, salah satunya adalah dengan melaksanakan promosi jabatan yang objektif dan adil serta penempatan yang tepat

3. Tujuan dan Manfaat Promosi Jabatan

a. Untuk memberikan pengakuan, jabatan, dan imbalan jasa yang semakin besar kepada karyawan yang berprestasi kerja tinggi.

b. Dapat menimbulkan kepuasan dan kebanggan pribadi, status sosial yang semakin tinggi, dan penghasilan yang semakinbesar.

c. Untuk merangsang agar karyawan lebih bergairah bekerja, berdisiplin tinggi, dan memperbesar produktivitskerjanya.

d. Untuk menjamin stabilitas ke pegawaian dengan direalisasikannya promosi kepada karyawan dengan dasar pada waktu yang tepat serta penilaian yang jujur.

4. Syarat- Syarat Promosi Jabatan

Untuk mendapatkan karyawan yang layak mendapatkan promosi jabatan, organisasi atau perusahaan harus memiliki syarat - syarat bagi karyawan untuk dipromosikan, sehingga promosi jabatan yang 
dilakukan diberikan kepada karyawan yang tepat. Hal tersebut penting untuk memotivasi karyawan untuk mencapai syarat-syarat promosi tersebut.

\section{METODE}

Penelitian dilakukan dengan tujuan untuk dapat mengungkapkan permasalahan yang di teliti. Penelitian ini bersifat kuantitatif dimana data kuantitatif adalah data yang bersifat terstruktur atau berpola sehingga ragam data yang diperoleh dari sumbernya (responden yang ditanyai atau objek yang diamati) cenderung memiliki pola yang lebih mudah dibaca oleh peneliti. Metode kuantitatif dilakukan melalui pendekatan korelasional digunakan untuk proses pengujian atau hipotesis penelitian yang diajukan, yaitu sejauh mana variasi pada suatu akar yang berkaitan dengan variasi akarlainnya.

Dalam penyusunan proposal skripsi ini diperlukan data yang relevan dengan obyek yang diteliti. Dan untuk pengumpulan data tersebut maka penulis dalam hal ini mengadakan penelitian pada PT. Permodalan Nasional Madani yang beralamat di Menara Taspen Gedung Arthaloka Jl. Jend. Sudirman, Kav.2, RT.10/RW.11, Karet Tengsin, Jakarta Pusat, Kota Jakarta Pusat, Daerah Khusus Ibu kota Jakarta 10250, Indonesia Telepon: (021) 2511404 (kantor pusat).

Tabel 1. Karakteristik Responden Berdasarkan Jenis Kelamin

\begin{tabular}{|cc|c|c|c|c|}
\hline & & Frequency & Percent & Valid Percent & Cumulative Percent \\
\hline Valid & Laki-Laki & 17 & 22,7 & 22,7 & 22,7 \\
& Perempuan & 58 & 77,3 & 77,3 & 100,0 \\
& Total & 75 & 100,0 & 100,0 & \\
\hline
\end{tabular}

Berdasarkan table diatas, untuk responden berjenis kelamin laki-laki sebanyak 17 orang atau 22,7\%. Juga responden yang berjenis kelamin perempuan sebanyak 58 orang atau $77,3 \%$.
Penelitian ini di lakukan selama 3 bulan yaitu bulan Januari - Maret 2020. Langkah - langkah yang penulis ambil dalam mengambil data pada penelitian ini dilakukan secara bertahap mulai dari izin kepada manajer HRD dan Finance untuk melakukan penelitian dan meminta data dengan wawancara dengan karyawan untuk mengetahui seberapa besar pengaruh Pelatihan dan Promosi Jabatan terhadap Kinerja kerja karyawan Pada PT. Permodalan Nasional Madani (persero).

\section{HASIL DAN PEMBAHASAN}

Untuk mengetahui secara pasti pengaruh Pelatihan dan Promosi Jabatan terhadap kinerja pegawai digunakan ilmu statistik sebagai instrumen pembuktian hipotesis. Pembahasan yang dilakukan dalam kerangka ini adalah untuk melihat apakah pelatihan dan promosi jabatan mempengaruhi secara signifikan terhadap kinerjapegawai.

Adapun karakteristik responden setelah kuesioner ini disebar, maka penelitian memperoleh data atau karakteristik responden PT. Permodalan Nasional Madani (persero).

1. Jenis Kelamin Responden

Berdasarkan jenis kelaminnya maka responden dalam penelitianini dapat di klasifikasikan sebagai berikut :
2. Usia Responden

Berdasarkan hasil tabulasi menurut usia, maka responden dalam penelitian ini adalah dapat di klasifikasikan seperti pada tabel 4.3 dibawah ini.

Tabel 2 Karakeristik Responden Berdasarkan Usia Responden

\begin{tabular}{|cc|c|c|c|c|}
\hline & & Frequency & Percent & Valid Percent & Cumulativ e Percent \\
\hline Valid $20-25$ & 33 & 44,0 & 44,0 & 44,0 \\
& $25-30$ & 12 & 16,0 & 16,0 & 60,0 \\
$30-35$ & 29 & 38,7 & 38,7 & 98,7 \\
40 & 1 & 1,3 & 1,3 & 100,0 \\
\hline Total & 75 & 100,0 & 100,0 & \\
\hline
\end{tabular}


Berdasarkan tabel diatas dapat dilihat, persentase usia responden PT. Permodalan Nasional Madani, usia 20-25 tahun sebanyak 33 orang atau $44 \%$, usia 25-30 tahunsebanyak 12 orang atau $16 \%$, 30-35 tahun sebanyak 29 orang atau $38,7 \%$, usia 40 tahun 1 orang atau 1,3\%

Tabel 3. Karakteristik Responden Berdasarkan Tingkat Pendidikan

\begin{tabular}{|c|c|c|c|c|}
\hline & Frequency & Percent & Valid Percent & Cumulative Percent \\
\hline Valid SMA/ SMK & 41 & 54,7 & 54,7 & 54,7 \\
S1 & 30 & 40,0 & 40,0 & 94,7 \\
S2/S3 & 4 & 5,3 & 5,3 & 100,0 \\
Total & 75 & 100,0 & 100,0 & \\
\hline
\end{tabular}

\section{KESIMPULAN}

Pelatihan dan Promosi jabatan mempunyai pengaruh yang positif dan signifikan terhadap kinerja Pegawai PT. Permodalan Nasional Madani (persero), hal ini di buktikan dengan uji hipotesis yang telah dilakukan

\section{DAFTAR PUSTAKA}

Anwar Prabu Mangkunegara, 2012. Manajemen Sumber Daya Manusia. Bandung: PT.. Remaja Rosdakarya

Affandi, A. (2020). OPT.imization of MSMEs Empowerment in Facing Competition in the Global Market during the COVID-19 Pandemic Time. Systematic Reviews in Pharmacy, 11(11), 1506-1515.

AM, E. N., et al (2020). Implementation of Human Resource Management in the AdaPT.ation Period for New Habits. International Journal of Educational Administration, Management, and Leadership, 19-26.

Danang Sunyoto. 2015. Manajemen dan Pengembangan Sumber Daya Manusia. Yogyakarta: Center for Academic Publishing Service

Ghozali, Imam. 2013. Aplikasi Analisis Multivariate dengan Program IBM SPSS 15 Update PLS Regresi. Semarang: Badan Penerbit Universitas Diponegoro.

Hamali, Arif Yusuf. 2016. Pemahaman Manajemen Sumber Daya Manusia. Bandung: Kencana.
3. Tingkat Pendidikan Responden

Berdasarkan tingkat pendidikan yang ditempuhnya, maka responden dalam penelitian ini dapat di klasifikasikan seperti pada tabel 4.4 dibawah ini:
Hanggraeni, Dewi. 2012. Manajemen Sumber Daya Manusia. Jakarta: LPFEUI Hasibuan. 2012. Pelatihan dan Kinerja. Jakarta: PT. Bumi Aksara. Imam Syatoto. Pengaruh Rekrutmen dan Pelatihan Terhadap Kinerja Karyawan Pada PT.. Radana Bhaskara Finance. Tbk.Jurnal Kreatif, Pamulang, 2018

Mangkunegara, Anwar Prabu. 2017. Manajemen Sumber Daya Manusia Perusahaan. Bandung: PT. Remaja Rosdakarya.

Moeheriono. 2012. Pengukuran Kinerja Berbasis Kompetensi. Jakarta: Rajawali Pers. Cetakan Pertama.

N. Lilis Suryani, Kiki Zakiah. Pengaruh Pelatihan Dan Disiplin Kerja Terhadap Kinerja Karyawan Pada PT.. Bank Negara Indonesia Di BSD Tangerang, Jurnal Kreatif, Pamulang, 2019

Noryani, Y. B. G., Sari, W. I., Rosini, I., Munadjat, B., Sunarsi, D., \& Mahnun Mas' adi, G. (2020). Did ISO 45001, ISO 22000, ISO 14001 and ISO 9001 Influence Financial Performance? Evidence from Indonesian Industries. PalArch's Journal of Archaeology of EgyPT./EgyPT.ology, 17(7), 69306950.

Wilandari, D. F., Sunarsi, D., \& Mas'adi, M. (2021). Pengaruh Penilaian Kerja Terhadap Kinerja Karyawan Pada PT.. Jaya Mandiri Rekabuana di Cilandak. Jurnal Ekonomi Efektif, $3(2)$. 